Dept. Theriogenology

Fac. of Vet. Med. Assiut Univ.

\title{
THE EFFECT OF STAGE OF BREEDING SEASON AND ADMINISTRATION OF FERTIRELIN ACETATE (GNRH ANALOGUE) POST-MATING ON OVARIAN ACTIVITY AND FERTILITY IN EWE LAMBS
}

(With 3 Tables)

\author{
By \\ A. EL-DIN ZAIN and M.T. MOUSA* \\ *Anim. Prod. Res. Station, Mallawi, Egypt.
}

(Received at 29/9/1999)

تأثير موسم التلقيح واعطاء الثهرمون الحاث

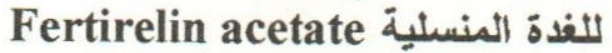

بعد التلقيح على النشاط المبيضى والخصوبله في حوليات الاغنام

علاء الدبين زبين العابلين محمود ، مصطفي توفيق موسى

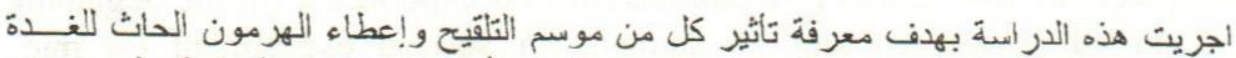

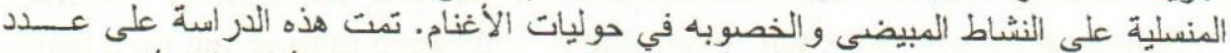

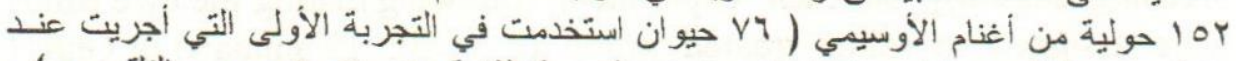

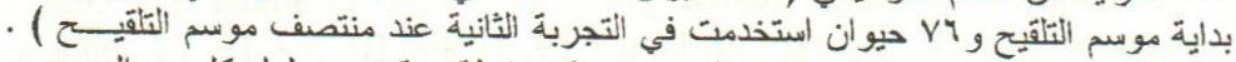

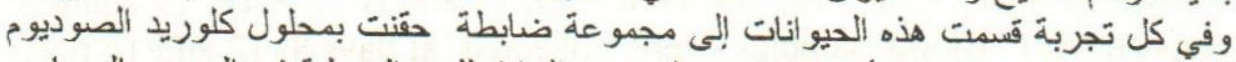

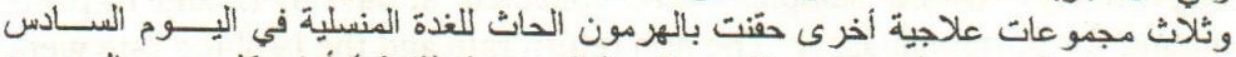

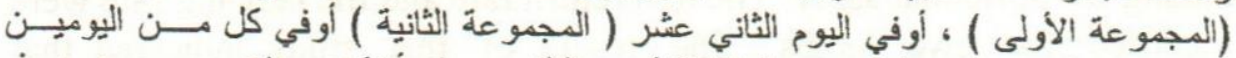

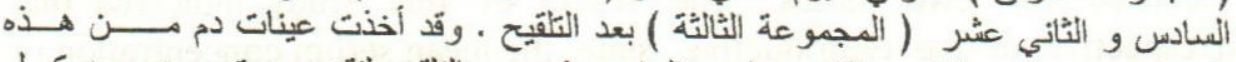

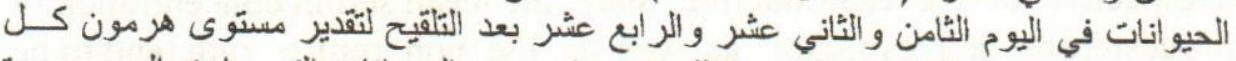

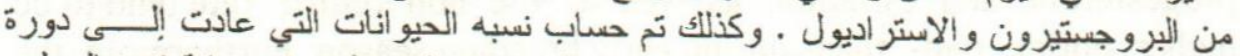

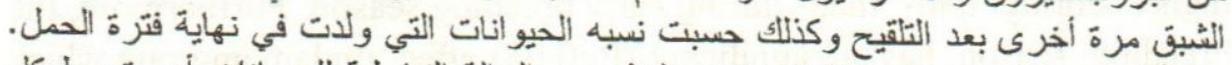

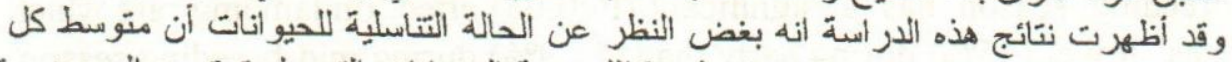

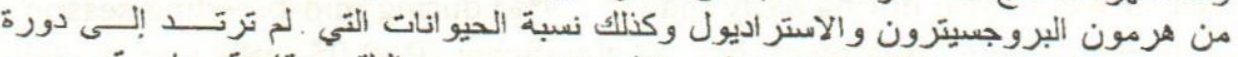

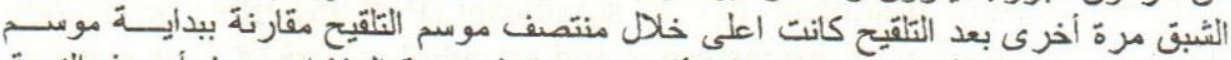

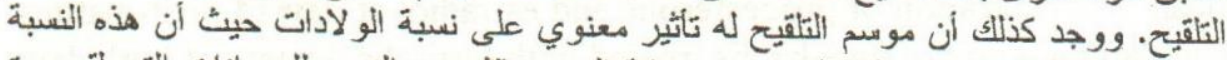

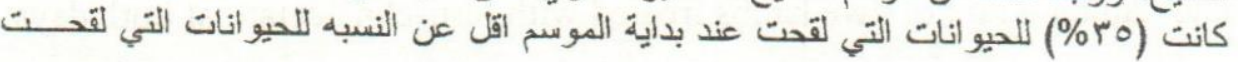




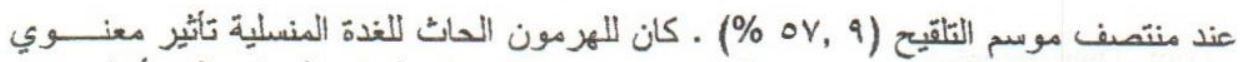

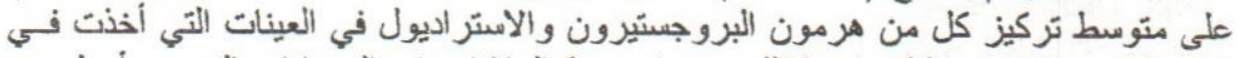

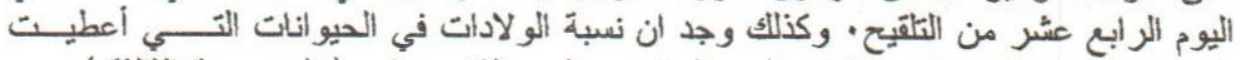

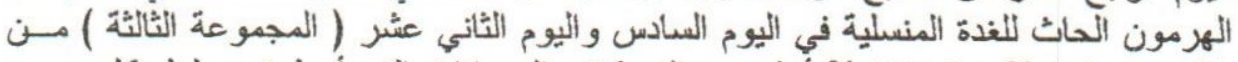

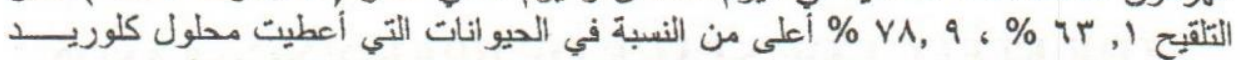

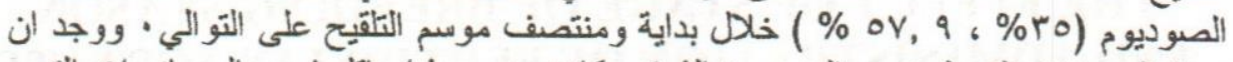

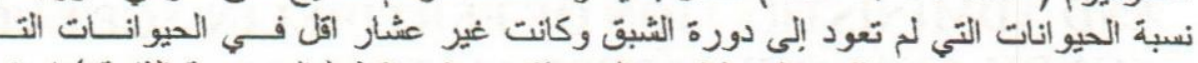

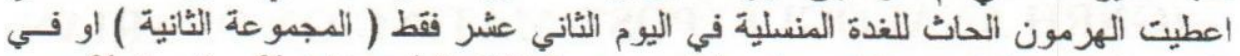

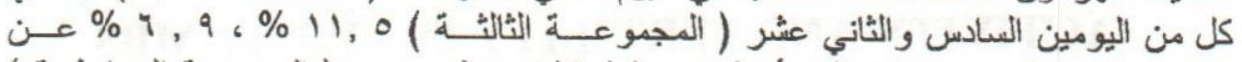

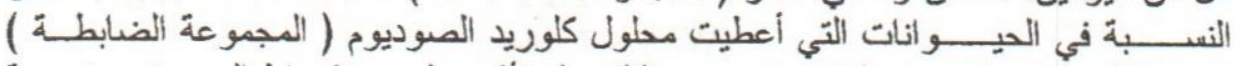

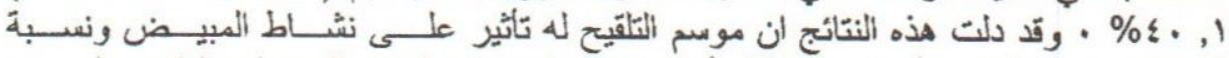

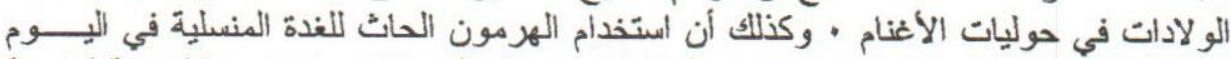

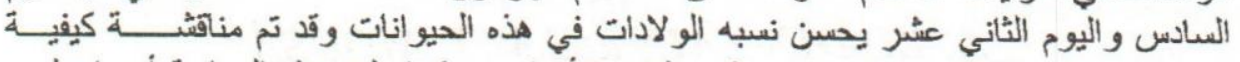

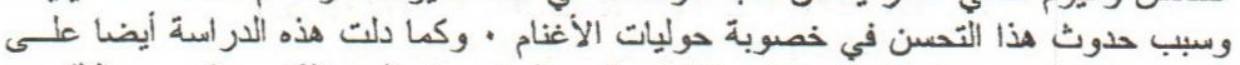

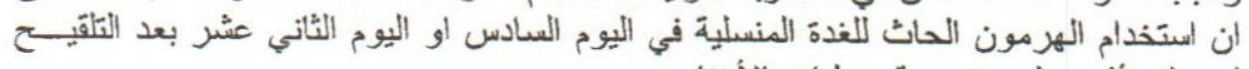

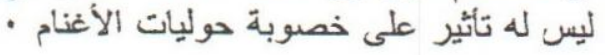

\section{SUMMARY}

A study was conducted to determine the effects of stage of breeding season and treatment with $\mathrm{GnRH}$ analogue (Fertierlin acetate) on day 6; day 12 or days $6 \& 12$ post-mating on ovarian activity and reproductive performance of ewe lambs. A total of 152 Ossimi ewe lambs were involved in this study [ 76 animals for first experiment (at the beginning of breeding season) and 76 animals for second experiment (at midbreeding season)]. In each experiment, following mating the ewe lambs were assigned to saline treated group ( $n=20 ; 19$ animals) or $\mathrm{GnRH}$ treated groups (I: $n=18,19 ; I I: n=19,19$ and III: $n=19,19$ animals, respectively). Blood samples were collected at days $8 ; 12$ and 14 postmating for hormonal assay. The non return rate and the lambing rate were recorded for ewe lambs. The result of this study indicated that irrespective of the reproductive state, the mean serum concentration of progesterone and estradiol, as well as the non return rate tend to be higher during mid- than during early breeding season. Furthermore, the breeding season has a significant $(\mathrm{P}<0.05)$ effect on lambing rate which was lower (35\%) during early than $(57.9 \%)$ during mid-breeding season. Fertirelin acetate treatment has a significant $(\mathrm{P}<0.05)$ effect on overall mean concentration of progesterone and estradiol at day 14 post-mating. The lambing rate of ewe lambs treated with fertirelin acetate at both days 
$6 \& 12$ (group III) either during early or mid stage of breeding season were significantly $(\mathrm{P}<0.05)$ higher $(63.1 \%$ and $78.9 \%)$ than those treated with saline solution ( $35 \%$ and $57.9 \%$ ), respectively. Moreover, fertirelin acetate treatment at day 12 (group II) or at both days $6 \& 12$ (group III) significantly $(\mathrm{P}<0.05)$ decrease the overall rates of non return and nonpregnant ewe lambs $(11.5 \%$ and $6.9 \%)$ compared with saline treated group (40.1\%), receptively. From the results of this study, it is concluded that: stage of breeding season affects both ovarian activity and lambing rate of Ossimi ewe lambs. Treatment with fertirelin acetate at days $6 \& 12$ post-mating improve lambing rate of ewe lambs and the mechanism by which treatment regime improve fertility was discussed. There was no effect when GnRH was given at day 6 or day 12 post-mating on lambing rate in Ossimi ewe lambs.

Key words: Ewelamb, GnRH, Season, Fertility, Ovarian activity

\section{INTRODUCTION}

The economic and biological significance of embryo mortality in sheep and other farm animals is well recognized. Although, it has been known that in the absence of infectious disease of the reproductive system, early embryonic death is important factor limiting reproductive efficiency in farm livestock (Peters, 1996). The reproductive performance of sheep does vary with age, breed, management and environmental factors (Quirke, 1981; Dyrmundsson, 1983).

In ewe lambs, the pre-implantation loss has been recognized as a major factor limiting both lifetime productivity and rate of genetic improvement in breeding programs (Dyrmundsson, 1973; Quirke et al., 1983). The time required from fertilization to the process of implantation is 16 days (Hodgen and Itskonitz, 1988). Most estimates of the extent of pre-implantation losses can account for up to $63 \%$ of fertilized ova in ewe lambs (Quirke et al., 1983). The majority of losses occurred within the first three weeks of gestation (Al-Wahab and Bryant, 1978) and this results in lower pregnancy rates and in reduced litter size (Quirke et al., 1983; McMillan and McDonald, 1985). Moreover, The majority of these losses are avoidable as a small percentage are the result of inherent embryonic abnormality and most of them are capable of normal development (Wilmut et al., 1986). Therefore, it should be possible to develop methods of preventing their loss.

Investigations on ewe lambs subfertility have established that the 
length of estrous cycles and fertilization rates are the same as in mature ewes (Quirke et al., 1983). However, ovulation rates are lower (Dyrmundsson, 1973) and embryonic mortality are higher than in mature ewes (Hamra and Bryant, 1979; Davies and Beck, 1993). There is evidence to suggest that fertility may vary with the stage of breeding season, which is positively correlated with the number of estrous cycles before the animals are mated (Beck and Davies, 1994). In addition, embryo loss was found to be $20 \%$ higher in animals mated at puberty compared with second or third estrous (Hare and Bryant, 1985). There is evidence that the lower ovulation rates and higher levels of embryonic mortality recorded for ewe lambs may be related to difference in hormones production (Davies and Beck, 1993). Inadequate luteal function has been shown to be an important cause of embryo loss (Wilmut et al., 1986; Ashworth et al., 1989). Plasma LH concentration during puberty and the early part of breeding season are reportedly lower than in adult estrous cycles (Karsch et al., 1983). Furthermore progesterone concentrations during early pregnancy appear lower and more variable in ewe lambs than in mature ewes (Davies and Beck, 1992; 1993). Therefore, the majority of attempts to reduce pre-implantation losses in ewe lambs have involved hormonal therapy during early pregnancy.

Many investigators used hormonal therapy to improve reproductive efficiency in farm animals. However, numerous studies have been conducted in mature ewes using exogenous hormones at the time of mating or post-mating, e.g. Human chorionic gonadotrophin (Kittok, et al., 1983); progesterone supplementation (Diskin and Niswender, 1989; McMillan, 1987) and gonadotrophin releasing hormone (Beck et al., 1994). Little literature is available for ewe lambs (Beck and Davies, 1994; Beck, et al., 1994), while local breeds lack available literature.

The objectives of this study were:

1) To determine the effects of stage of breeding season or GnRH injection post-mating on ovarian activity in Ossimi ewe lambs.

2) To compare the reproductive performance of Ossimi ewe lambs mated at the beginning or at the middle of breeding season under subtropical conditions.

3) To determine the effects of $\mathrm{GnRH}$ analogue (Fertirelin acetate, 50 $\mu \mathrm{g})$ given at day 6 or at day 12 or at both day 6 and 12 after mating either at the beginning or at the middle of breeding season on fertility in Ossimi ewe lambs. 


\section{MATERIAL and METHODS}

\section{Animals and management:}

A total of 152 Ossimi ewe lambs from four flocks, in good body condition, 10-12 months old [at the beginning of May (the breeding season of Ossimi breed, El-Fouly et al., 1977)] with an average live weight $25-30 \mathrm{Kg}$ were used in this study. These flocks are located at Malawi and Der Mawas districts, El-Minia Governorate, Egypt (a subtropical zone around $27^{\circ}, 30 \mathrm{~N}$ ). The ewe lambs are housed with teaser rams under conditions of natural day-length and temperature. The animals detected to be in estrus were naturally mated twice daily by fertile rams. The animals were grazing on Egyptian Clover (T. alexandrinum) from December to May. Thereafter, they were fed on crop residues available in summer season and green forage (Darawa). Fresh water was available ad libitum. Adequate concentrates were added according to weight and physiological stages. All ewe lambs were judged to be free of physical defects and had normal external genitalia.

\section{Experimental procedures:}

Commencing in middle of April (just before the beginning of breeding season), the initial selection of ewe lambs for this study was made and divided for using in two experiments. The first experiment $(\mathrm{n}=$ 76 ewe lambs) started at the beginning of breeding season (beginning of May) and the second experiment $(n=76$ ewe lambs) started at the mid of breeding season (mid of June).

Following mating, the ewe lambs in each experiment were randomly assigned to saline treated group [received a single dose or double doses of i.m. injections of saline $(1 \mathrm{ml}$ of $0.9 \% \mathrm{NaCl}$ solution, placebo) and served as control $(n=20 ; 19$ ewe lambs) ] or GnRH treated group [received a dose of $50 \mu \mathrm{g}$ fertirelin acetate $\mathrm{GnRH}$ analogue $(1 \mathrm{ml}$ of Conceral, Takeda Co. Japan)]. In both experiments, the GnRH treated group were allocated to one of three treatment trials: (I) the ewe lambs treated $(\mathrm{n}=18 ; 19)$ by one dose on day 6 post-mating; (II) the ewe lambs treated by one dose $(n=19 ; 19)$ on day 12 post-mating; and (III) the ewe lambs treated by two doses $(n=19 ; 19)$, the first dose on day 6 and the second dose on day 12 post-mating.

Blood samples $(5 \mathrm{ml})$ were collected between 8.00 to 10.00 A.M. from the ewe lambs by jugular veinpuncture at days $8 ; 12$ and 14 after mating (either treated with saline or $\mathrm{GnRH}$ ) to assess the effect of stage 
of breeding season and treatment on ovarian activity. Immediately after collection, the samples were transformed to the refrigerator (at $5^{\circ} \mathrm{C}$ ) and allowed to clot overnight, then centrifuged at $3000 \mathrm{~g}$ for $10 \mathrm{~min}$., the serum was separated and kept frozen at $-20^{\circ} \mathrm{C}$ until assayed. The samples of 56 animals [ 20 ewe lambs treated with saline ( 10 per experiment, including 5 pregnant and 5 non-pregnant) and 36 ewe lambs (18 animals per experiment) treated with $\mathrm{GnRH}$ (6 pregnant per GnRH treatment)] were selected for determination of progesterone concentrations at days 8 ; 12 and 14 post-mating and estradiol concentrations at day 14 postmating. Serum progesterone and estradiol concentrations were determined by RIA method (Coated-A-Count progesterone and estradiol, Diagnostic Products Co. Los Angeles, U.S.A.).

All animals were kept under observation until lambing. The mated ewe lambs were checked for estrus twice daily with teaser rams for three weeks post-mating to determine the return to service. At lambing, the date of birth, number and viability of lambs were recorded for each ewe lamb.

\section{Statistical analysis:}

Stage of breeding season (beginning or middle of breeding season); treatment (saline or GnRH); time of GnRH treatment (day 6; day 12; days 6 and 12 after mating); flocks (four) were recorded for each animal.

The data of 152 ewe lambs were analyzed by analysis of variance using procedures of the statistical analysis system (SAS, 1988). The nonreturn rates and lambing rates were the response effects of stage of breeding season or treatment. Differences in non-return rates; lambing rates and hormonal levels (progesterone and estradiol hormones) were compared between treatment groups in both experiments by Chi-square analysis using Yate,s correction for continuity (Parkar, 1976) and T. test, respectively.

\section{RESULTS}

The effects of stage of breeding season and reproductive state on ovarian activity in ewe lambs are presented in table 1. During both early and mid-breeding season, The mean serum concentrations of progesterone were higher at all days of sampling in pregnant ewe lambs than non-pregnant ones. This differences were statistically significant $(\mathrm{P}<0.05)$ at days 12 and 14 post-mating. However, The mean serum 
concentrations of estradiol at day 14 post-mating was significantly lower $(\mathrm{P}<0.05)$ in pregnant ewe lambs $(0.95 \pm 0.04$ and $0.98 \pm 0.02 \mathrm{pg} / \mathrm{ml})$ than non-pregnant ones $(1.27 \pm 0.04$ and $1.38 \pm 0.08 \mathrm{pg} / \mathrm{ml})$ at both early and mid-breeding seasons, respectively. Moreover, the mean serum concentrations of progesterone and estradiol tend to be higher in both pregnant and non-pregnant during mid- than early breeding season and this difference was not statistically significant (Table 1).

The combined data of pregnant ewe lambs for the effect of administration of $\mathrm{GnRH}$ at days $6 ; 12$ and days $6 \& 12$ post-mating on ovarian activity during early and mid-breeding season are given in table 2 . However, there was no effect of administration of $\mathrm{GnRH}$ on overall mean serum concentrations of progesterone at days 8 and 12 post-mating. The time of administration of Fertirelin acetate ( $\mathrm{GnRH}$ analogue) has significant effect $(\mathrm{P}<0.05)$ on serum concentrations of progesterone at day 14 post-mating. The overall mean serum concentration of progesterone was significantly $(\mathrm{P}<0.05)$ higher $(1.83 \pm 0.06$ and $1.91 \pm 0.13$ $\mathrm{ng} / \mathrm{ml}$ ) for $\mathrm{GnRH}$ treatment groups II and III, respectively than $(1.67 \pm 0.06 \mathrm{ng} / \mathrm{ml})$ in $\mathrm{GnRH}$ treatment group I. Moreover, The overall mean serum concentrations of estradiol were $0.99 \pm 0.06 ; 0.76 \pm 0.10$ and $0.58 \pm 0.05 \mathrm{pg} / \mathrm{ml}$ for different $\mathrm{GnRH}$ treatment groups (I; II and III, respectively) and this difference was statistically significant $(P<0.05)$ (Table 2).

The reproductive performance of both experiments (early and mid-breeding season) and of four treatments [saline and GnRH (I; II and III)] is given in table 3 . However, the breeding season has significant $(\mathrm{P}<0.05)$ effect on number of animals lambing. The lambing rate was lower (35.0) during early breeding season than during mid-breeding season (57.9). Moreover, the proportion of ewe lambs not returning to estrous tend to be higher during mid-breeding season than during early and this difference was not statistically significant (Table 3).

Fertirelin acetate was not effective in increasing significantly non return rate and the lambing rate of ewe lambs compared with saline treated group (control) when administered at days 6 or 12 post-mating (treatment groups I and II) either during early or mid-breeding season (Table 3). However, when given at both days $6 \& 12$ (treatment group III) either during early or mid- breeding season, the lambing rate increased significantly $(\mathrm{P}<0.05)$ by $28.1 \%$ and 21.0 , respectively when compared with saline treated group (Control). Moreover, the percent of 
animals not returning to estrous and non-pregnant decreased significantly $(\mathrm{P}<0.05$ ) by $33.3 \% ; 42.3 \%$ and $24.1 \% ; 25.0 \%$ (groups II and III) than saline treated group either during early and mid-breeding season, respectively. The overall lambing rate of ewe lambs given $\mathrm{GnRH}$, regardless of the stage of breeding season, increased to 71.0 compared to 46.1 of the control group and this differences were statistically significant $(\mathrm{P}<0.05)$. As well as, the overall percent of animals not return to estrous and non-pregnant decreased significantly $(\mathrm{P}<0.05)$ by $28.5 \%$ and $33.1 \%$ for GnRH treatment groups II and III, respectively than saline treated group.

The time of administration of Fertirelin acetate ( $\mathrm{GnRH}$ analogue) has a significant $(\mathrm{P}<0.05)$ effects on overall lambing rate and the percent of ewe lambs not return to estrous and non-pregnant. The percent of ewe lambs not return to estrous and non-pregnant was lower by $16.6 \%$; $25.6 \%$ and $13.6 \%$ and $20.5 \%$ for GnRH treated groups II and III, respectively when compared with $\mathrm{GnRH}$ treated group I, during both early and mid-breeding season or when combined the data of two stages of breeding season. The overall lambing rate significantly increased by $19.7 \%$ for ewe lambs treated at both days $6 \& ! 2$ post-mating (group III), when compared with ewe lambs treated at day 6 post-mating (Table 3 ).

\section{DISCUSSION}

During the breeding season, formation and regression of the corpus luteum occurs cyclically in non-pregnant ewes. However, the processes regulating luteolysis are circumvented during early pregnancy due to the production of chemical signals which is secreted transiently by the conceptus beginning on day 12 of pregnancy (Knickerbocker and Niswender, 1989), at time corresponds to maternal recognition of pregnancy in ovine species (Moor and Rowson, 1966). Successful implantation and development of the conceptus is dependent upon secretion of steroid hormones from the ovary (Thatcher et al., 1989).

In the present study, irrespective of the reproductive state (nonpregnant or pregnant), the obtained data indicated that the pattern of steroid hormones secretion in ewe lambs was lower at early stage than for mid stage of breeding season. This was consistent with that found by Wilmut et al. (1985); Diskin and Niswender (1989) who demonstrated that peripheral progesterone concentration is higher at mid-breeding 
season than at the beginning or end of breeding season. This is a direct effect of inadequate function of corpora lutea which could be attributed to the seasonal changes in follicular growth, pattern of $\mathrm{LH}$ secretion and ovulation rate. The pattern of $\mathrm{LH}$ secretion is important for antral follicular growth and maturation (Ravindra, et al., 1994) and play a crucial role in the maintenance of luteal function (Baird, 1992). The LH concentration during puberty and early part of breeding season was lower than during mid-breeding season (Karsch et al., 1983). Therefore, lower LH secretion at puberty and at the beginning of breeding season affect the follicular growth and consequently ovulatory rate and activity of corpora lutea of ewe lambs at the beginning of breeding season.

In this study, irrespective of the stage of breeding season, the pattern of progesterone and estradiol secretion in both non-pregnant and pregnant ewe lambs at days $8 ; 12$ and 14 post-mating was similar to that reported by Ashworth et $\underline{\text { al }}$. (1989); Davies and Beck (1992; 1993). Moreover, The pattern of steroid hormones secretion was lower in ewe lambs than reported for mature ewes (Davies and Beck, 1993; Abecia et

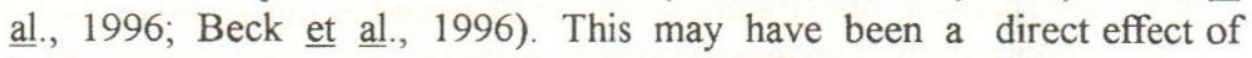
inadequate progesterone priming during follicular phase, lead to lower estradiol secretion from preovulatory follicles, as shown in our study, which has been associated with lower luteal function in ewe lambs. This is thought to allow the ovulation of immature follicles (Hunter, 1991), which as a result of being exposed to a smaller preovulatory LH surge, become less luteinized than normal follicles and subsequently become inadequate function of corpora lutea (Baird, 1992). The smaller preovulatory LH surge was recorded for non-pregnant or pregnant ewe lambs (Davies and Beck, 1993) when compared with mature ewes. Therefore smaller preovulatory LH surge could be explained the lower level of progesterone in ewe lambs at day 14 post-mating than for mature ewes either non-pregnant or pregnant. In addition the present study revealed that post-mating progesterone concentration remained below 1 $\mathrm{ng} / \mathrm{ml}$ for 7 days in barren ewe lambs, indicating that luteal function was abnormal, as well as in comparison with barren ewe lambs progesterone concentration was higher and luteal function was normal in fertile groups. These results confirms an earlier report by (Davies and Beck, 1992), who suggested that barrenness in ewe lambs is associated with luteal inadequacy. Furthermore, The difference in progesterone concentration between non-pregnant and pregnant ewe lambs was the result of embryonic factors stimulating luteal function in pregnant ewe lambs and 
protecting the corpus lutem from luteolytic factor secreted from the endometrium at time of luteolysis in non-pregnant animals. The higher estradiol concentrations observed in non-pregnant ewe lambs on day 14 post-mating was probably the result of follicular growth and development prior the onset of next oesrtus. Recently, Ravindra et al . (1994) studied the ovarian follicular dynamics in ewes and observed that there are two major phases of growth of large antral follicles on days 2 and 11 of the cycle.

The effects of administration of fertirelin acetate on the ovarian activity are similar to that reported in recent study in mature ewe (Beck et al., 1996) who investigated the physiological and ovarian changes brought about by $\mathrm{GnRH}$ treatment on day 12 post-insemination. The administration of GnRH post-mating induces a gonadotrophin surge which causes the ovulation or atresia of developing follicles (Mann and Picton, 1995) which are associated with a transient increase in progesterone concentration. Similar increase in progesterone concentration was observed especially at day 14 post-mating in our study. The pattern of estradiol secretion observed in this study is similar to that reported by Davies and Beck (1992). The Latter showing that buserelin treatment resulted in lower plasma estradiol concentration during days 13 to 15 post-insemination. Previous studies indicating that both progesterone and estradiol affect endometrium morphology (Murray,1992); involved in regulating the development of uterine oxytocin receptors (Vallet et al., 1990); Endometrial production of $\mathrm{PGF}_{2}$ $\alpha$ (Bergeron and Goff, 1993) and influence uterine protein and carbohydrates production (Murray and Sower, 1992).

The results of this study indicated that lambing rate of ewe lambs is higher during mid stage than during early stage of breeding season. This agree with earlier reports of seasonal rise in fertility in ewe lambs (Bichard et al., 1974; Hare and Bryant, 1985). Furthermore, these differences in lambing rate was the result of an improvement in embryo survival which is a direct effect of improvement of uterine microenvironment. This suggestion gains support from increased pattern of steroid hormones secretion of the ovary as the breeding season passed from early to mid-stage. Moreover, these results confirms the observations of Beck and Davies (1994) that fertility improve as the reproductive system matures during subsequent estrus cycles.

Recently, different techniques developed to overcome early embryonic death in ovine caused by inadequate luteal function have 
produced in consistent results (Kittok, et al., 1983; Mcmillan, 1987; Diskin and Niswender, 1989; Beck and Davies, 1994; Beck et al., 1994). Rosenberg et al. (1991) suggested that GnRH may affect several stages of the reproductive processes and that consequently different animals may benefit from $\mathrm{GnRH}$ administration through different mechanisms. Different treatment regimes were designed to investigate the additive effects of Fertirelin acetate (GnRH analogue) on reproductive performance of ewe lambs. The results of this study showed evidence of beneficial effect from $\mathrm{GnRH}$ analogue treatment for ewe lambs. There was a significant improvement of lambing rate of ewe lambs by $\mathrm{GnRH}$ administered at both days $6 \& 12$ post-mating. However, there was no effect from $\mathrm{GnRH}$ administered both at day 6 or day 12 post-mating.

There is very little comparable information about the effect of $\mathrm{GnRH}$ treatment in ewe lambs. Therefore, our results are comparable with results of $\mathrm{GnRH}$ treatment in mature ewes. The overall affects of GnRH treatment in this study is similar to the results of previous studies that reported an improvement of reproductive performance of mature ewes treated with $\mathrm{GnRH}$ at day 12 post-mating (McMillan, et al., 1986; Beck et al., 1994). In our study the overall non-returning rate either for saline or GnRH treated groups was higher compared with that reported in previous studies (Hamra and Bryant, 1979; Quirke et al., 1983). In mature ewes, the number of animals returning to oestrus can be used to estimate conception rate. Since normally the animals which do not return are pregnant. However, in case of ewe lambs factors other than pregnancy may prevent animals returning oestrus (Davies and Beck, 1992). These are: 1) short breeding season which followed by anestrous (Quirke et al., 1983). 2) Prolonged diestrus which are indicating of luteal persistence caused by embryonic mortality after day 12 of pregnancy (Edey, 1967; Davies and Beck, 1992). Therefore, the non-return rate in our study most probably overestimated fertility and more accurate estimate of fertility was obtained from lambing rate.

In ovine species, the embryonic mortality is maximal during implantation (Bolet, 1986). The increased number of ewe lambs nonreturn and non-pregnant, especially for saline treated group either at early or mid-stage of breeding season may indicate that early embryonic mortality is a significant cause of infertility in ewe lambs. This lead to luteal persistence which is evident in progesterone profiles of barren animals (Davies and Beck, 1992), and the later occurns the more diestrus is prolonged (Edey, 1967). 
The possible mechanism by which GnRH act to improve the lambing rate of ewe lamb is an the induction of LH surge which aid in the maintenance of function of corpora lutea and or luteinizing the growing follicles which in tern increase the progesterone levels and lower the estradiol levels that increase the embryonic survival rate. Therefore, It seems reasonable to suggest that fertirelin acetate may increase the chances of embryonic survival by (1) improving luteal function because insufficiency of progesterone has been implicated as a cause of abnormal development of embryo and early embryonic death (Davies and Beck, 1992). (2) Interfering with luteolytic mechanism which occurs normally as a result of release of $\mathrm{PGF}_{2} \alpha$ which caused by oxytocin binding to it's receptors in the uterus (Beard and Lamming, 1994). The appearance of these receptors is dependent on estradiol secretion by developing follicles

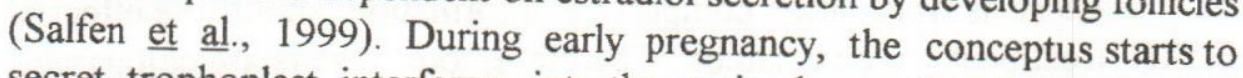
secret trophoplast interferon into the uterine lumen (Knickerbocker and Niswender, 1989). This has a direct inhibitory effect on oxytocin receptors development (Horn et al., 1998) and decreases the concentration of estradiol receptors within uterus (Lamming et al., 1995). This lead to suppression of $\mathrm{PGF}_{2} \alpha$ release and thus prevent luteolysis. However, if interferon production is insufficient, the processes of luteolysis would still occur unless the estradiol induced increase in uterine oxytocin was blocked (Beard et al., 1994; Horn et al., 1998). In fertirelin acetate treated ewe lambs, the estradiol secretion was decreased at day 14 post-mating due to luteinized or ovulating of any developing follicles as a result of stimulating the $\mathrm{LH}$ surge. This decrease of estradiol secretion would: (1) delay or prevent luteolysis and allow the less viable embryos longer to establish pregnancy by secreting interferon and thus survive (Beck et al., 1996). (2) Remove the non-adhesive mucins at the apical surfaces of uterine mucosa to generate a surface receptive to embryo attachment (Carson et al., 1998). This confirm our results that $\mathrm{GnRH}$ treatment (GnRH treated groups, II; III) decrease the number of ewe lambs non return and non-pregnant compared with control group. As well as when compared with GnRH treated group (I), which may be related to high level of estradiol as a result of secretion from antral follicles emerges at day 11 post-oestrus. (Ravindra et al., 1994).

In conclusion, the results of this study demonstrated that ovarian activity changes as well as lambing rate increases as the breeding season passed from early stage to mid stage. Moreover, Administration of Fertirelin acetate enhance the luteal function and improve lambing rate of 
ewe lambs. Although, the treatment regime described in this study affect ovarian activity and fertility of ewe lambs. The continued research to provide understanding the mechanism of action of GnRH and it's profertility effect in different treatment regimes for treatment subferility of ewe lambs are recommended.

\section{ACKNOWLEDGMENT}

The authors wish to thank Prof. Dr. T. Nakao, Head of Dept. Developmont Technology, School Int. Development and Cooperation, Hiroshina Univ., and Takeda Chemical Industries, Japan for donating the fertirelin acetate used in this study.

\section{REFERENCES}

Abecia, J.A.; Rhind, S.M.; Goddard, P.J.; McMillen, S.R.; Ahmadi, S. and Elston, D.A. (1996): Jugular and ovarian venous profiles of progesterone and associated endometrial progesterone concentrations in pregnant and non-pregnant ewes. J.Anim. Sci. (63): 229-234.

Al-Wahab, R.M.H. and Bryant, M.J. (1978): Reproduction in young female sheep induced to breed at various ages. Anim. Prod. (26): 309-316.

Ashworth, C,J;.Sales, D.I. and Wilmut, I (1989): Evidence for an association between the survival of embryos and periovulatory plasma progesterone concentration in the ewe. J.Reprod. Fertil (87):23-32.

Baird, D.T. (1992): Luteotrophic control of the corpus luteum. Anim. Reprod. Sci. (28): 95-102.

Beard, A.P.; Hunter, M.G. and Lamming, G.E. (1994): Quantitative control of oxytocin-induced $\mathrm{PGF}_{2} \alpha$ release by progesterone and oestradiol in ewes. J.Reprod.Fertil. (100): 145-150.

Beard, A.P. and Lamming, G.E. (1994): Oestradiol concentration and the development of uterine oxytocin receptors and oxytocininduced $\mathrm{PGF}_{2} \alpha$ release in ewes. J.Reprod.Fertil. (100): 469-475.

Beck, N.F.G. and Davies, M.C.G. (1994): The effect of stage of breeding season or pre-mating estrogen and progestagen therapy on fertility in ewe lambs. Anim. Prod. (59): 429-434. 
Beck, N.F.G.; Jones, M.; Davies, M.C.G.; Mann, C.A. and Peters, A.R. (1996): The effect of $\mathrm{GnRH}$ analogue (buserelin) treatment on day 12 postmating on ovarian structure and plasma progesterone and oestradiol concentrations in ewe. J.Anim. Sci. (63): 407-412.

Beck, N.F.G.; Peters, A.R. and Williams, S.P. (1994): The effect of GnRH agonist (Buserelin) treatment on day 12 post-mating on the reproductive performance of ewes. Anim. Prod. (58): 243-247.

Bergeron , H. and Goff, A.R. (1993): Effects of progesterone and oestradiol on oxytocin stimulation of prostaglandin $\mathrm{F}_{2} \alpha$ and $\mathrm{E}_{2}$ release by stromal and epithelial cells of bovine endometrium. Biol. Reprod. (48): 115 Suppl.1.

Bichard, M. Younis, A.A.; Forrest, P.A. and Cumberland, P.H. (1974): Analysis of production records from a lowland sheep flock. 4.factors influencing the incidence of successful pregnancy in young females. Anim. Prod, (19): 177-191.

Bolet, G. (1986): Timing and extent of embryonic mortality in pigs, sheep and goats: genetic variability, In embryonic mortality in farm animals (ed.J.M. Sreenan and M.G. Diskin), pp. 13-43. Martinus, Nijhoff, the Hague.

Carson, D.D; Desouza, M.M.; Kardon, R. Zhou, X.; Lagow, E. and Julian, J. (1998): Mucin expression and function in the female reproductive tract. Human Reprod. update, 4 (5): 459-464.

Davies, M.C.G. and Beck, N.F.G. (1992): Plasma hormone profiles and fertility in ewe lambs given progesterone supplementation after mating. Theriogenology (38): 513-526.

Davies, M.C.G. and Beck, N.F.G. (1993): A comparison of plasma prolactin, $\mathrm{LH}$ and progesterone concentrations during oestrus and early pregnancy in ewe lambs and ewes. Anim.Prod. (57): 281286.

Diskin, M.G. and Niswender, G.D. (1989): Effect of progesterone supplementation on pregnancy and embryo survival in ewes. $\mathbf{J}$. Anim. Sci. (6): 1559-1563.

Dyrmundsson, O.R. (1973): Puberty and early reproductive performance in sheep. I ewe lambs. Anim. Breeding Abs. (41): 272-289.

Dyrmundsson, O.R. (1983): The influence of environment factors on the attainment of puberty in ewe lambs. In sheep production (ed.W., Haresign), pp.393-408. Butterworths, London.

Edey, T.N. (1967): Early embryonic death and cycle length in the ewe J.Reprod. Feril. (13): 437-443. 
El-Fouly, N.A.; Shafi, M.M.; Abdel-Aziz, A.S. and Kandeal, S.A. (1977):

Seasonal variation in estrous activity in Ossimi and Rahmani ewes. Egypt. J. Anim. Prod. (17): 83-93.

Hare, L. and Bryant, M.J. (1985): Ovulation rate and embryo survival in young ewes mated either at puberty or second or third oestrus. Anim. Reprod. Sci. (8): 41-52.

Hamra, A.M. and Bryant, M.J. (1979): Reproductive performance during mating and pregnancy in young female sheep. Anim. Prod. (28): 235-243.

Hodgen, G.D. and Itskonitz, J. (1988): Recognition and maintenance. In: E. Knobil and J. Neil (Editors), The physiology of reproduction. Raven Press, New york, pp. 1995-2021.

Horn, S.; Bathgate, R.; Lioutas, C.; Brachken, K. and Ivell, R. (1998): Bovine endometrial epithelial cells as a model to study oxytocin receptors regulation. Human Reprod. update, 4 (5): 605-614.

Hunter, M.G. (1991): Characteristics and causes of the inadequate corpus luteum. J.Reprod. Fertil. (43): 91-99.

Karsch, F.G.; Foster, D.C.; Bittman, E.L. and Goodman, R.L.(1983): A role for oestradiol in enhancing $\mathrm{LH}$ pulse frequency during the follicular phase of the estrous cycle of sheep. Endocrinology (113): 1333-1339.

Kittok, P.J; Stellflug, J.N. and Lowery, S.R. (1983): Enhanced progesterone and pregnancy rate after gonadotrophin administration in lactating ewes. J. Anim. Sci.. (56): 652-655.

Knickerbocker, J.J. and Niswender, G.D. (1989): Characterization of endometrial receptors for ovine trophoblast protein-1 during the estrous cycle and early pregnancy in sheep. Biol. Reprod. (40): 361-369.

Lamming, G.E. Walhes, D.C.; Flint, A.P.E.; Payne, J.A.; Stevenson, K.R. and Vallet, J.L. (1995): Local action of trophoplast interferons in suppression of the development of oxytocin and oestradiol receptors in ovine endometrium. J.Reprod. Feril. (105): 165-175.

Mann, G.E. and Picton, H.M. (1995): Ovarian and uterine effects of a single buserelin injection on day 12 of the oestrous cycle in cow. J.Reprod. Fertil. Abst. Series 15:16 (Abst).

McMillan, W.H. (1987): Post-mating progesterone supplementation in ewes and hoggets. Proceedings of Newzealand Society of Anim. Prod. (47): 151-153. 
McMillan, W.H.; Knight, T.W. and Macmillan, K.L. (1986): Effects of gonadotropin releasing hormone (buserelin) on sheep fertility. Proceedings of the New Zealand Society of Anim. Prod. (46): 161-163.

McMillan, W.H. and McDonald, M.F. (1985): Survival of fertilized ova from ewe lambs and adult ewes in uteri of ewe lambs. Anim.

Reprod. Sci. (8): 235-240.

Moor, R.M. and Rowson, L.E.R. (1966): The corpus luteum of the sheep: functional relationship between the embryo and the corpus luteum. J. Endocrinol. (34): 233-239.

Murray, M.K. (1992): The effect of oestrogen and progesterone on structural changes in the uterine glandular epithelium of ovariectomized ewes. Biol. Reprod. (47): 408-417.

Murray, M.K. and Sower, S.A. (1992): Estrogen and progesteronedependent secretary changes in the uterus of the sheep. Biol. Reprod. (47): 917-924.

Parkar, R.E. (1976): Use of $\mathrm{X}^{2}$ : Single Classifications . In. : Parkar, R.E. (Ed.), Introductory statistics for biology. Edward Arnold, London, pp. 35-40.

Peters, A.R. (1996): Embryo mortality in cow. Anim.Breeding Abs. 64; (8); 587-598.

Quirke, J.F. (1981): Regulation of puberty and reproduction in female lambs- a review. Livestock production science (8): 37-53.

Quirke, J.F.; Adams, T.E. and Hanrahan, J.P. (1983): Artificial induction of puberty in ewe lambs. In sheep production (ed.W. Haresign) pp. 409-429. Butterworths, London.

Ravindra, J.P.: Rawlings, N.C.: Evans, A.C.O. and Adams, G.P. (1994):

Ultrasonographic study of ovarian follicular dynamics in ewes during the oestrous cycle. J.Reprod. Fertil. (101): 501-509.

Rosenberg, M.; Chun, M. Kaim, M.; Herz, Z. and Folman, Y. (1991):

The effect of $\mathrm{GnRH}$ administered to dairy cows during estrous on plasma $\mathrm{LH}$ and conception in relation to the time of treatment and insemination. Anim. Reprod Sci. (24): 13-24

Salfen, B.E.; Cresswell, J.R. Zu, Z.Z.; Bao, B. and Garverick, H.A (1999): Effects of presence of a dominant follicles and exogenous oestradiol on the duration of the luteal phase of the bovine oestrous cycle. J.Reprod. Fertil. (115): 15-21.

SAS. (1988): SAS' User's Guide: Statistic. SAS Institute, InE. Carg, NC. 
Thatcher, W.W.; Macmillan, K.L.; Monsen, P.J. and Dorst, M. (1989): Conceptus for regulation of corpus luteum and ovarian follicles to improve fertility. Theriogenology (31): 149-164.

Vallet, J.L.; Lamming, G.E. and Batten, M. (1990): Control of endometrial oxytocin receptors and uterine response to oxytocin by progesterone and oestradiol in the ewe. J.Reprod. Fert. (90): 625-634.

Wilmut, I.; Sales, D.I. and Ashworth, C.J. (1985): Physiological criteria for embryo mortality. Is a synchrony between embryo and ewe a significant factor? In Rand, R.B. and Robertson, P.W. (Ed) Genetics of reproduction in sheep. pp. 275-289. Butterworth, London.

Wilmut, I. Sales, D.I. and Ashworth, C.J. (1986): Maternal and embryonic factors associated with prenatal loss in mammals. J.Reprod.Fertil. (76): 851-864.

Table 1: Effect of stage of breeding season and reproductive state on ovarian activity in the control ewe lambs

\begin{tabular}{|l|c|c|ccc|c|}
\hline $\begin{array}{c}\text { Stage of } \\
\text { Breeding } \\
\text { season }\end{array}$ & $\begin{array}{c}\text { Reprod. } \\
\text { State }\end{array}$ & $\begin{array}{c}\text { No. of } \\
\text { Ewe } \\
\text { Lambs }\end{array}$ & \multicolumn{2}{|c|}{ Serum $\mathbf{P}_{4}$ Conc. $(\mathrm{ng} / \mathrm{ml})^{*}$} & $\frac{\text { Serum } \mathrm{E}_{2}}{\frac{\text { Conc. }}{(\mathrm{pg} / \mathrm{ml})^{*}}}$ \\
\hline Early & Non-pregnant & 5 & $1.05 \pm 0.14^{\mathrm{a}}$ & $0.98 \pm 0.09^{\mathrm{c}}$ & $0.61 \pm 0.13^{\mathrm{bc}}$ & $1.27 \pm 0.04^{\mathrm{c}}$ \\
\hline Pregnant & 5 & $1.23 \pm 0.15^{\mathrm{a}}$ & $1.29 \pm 0.15^{\mathrm{d}}$ & $1.61 \pm 0.04^{\mathrm{bd}}$ & $0.95 \pm 0.04^{\mathrm{d}}$ \\
\hline Mid. & Non-pregnant & 5 & $1.10 \pm 0.16^{\mathrm{a}}$ & $1.06 \pm 0.16^{\mathrm{c}}$ & $0.67 \pm 0.14^{\mathrm{bc}}$ & $1.38 \pm 0.08^{\mathrm{c}}$ \\
& Pregnant & 5 & $1.39 \pm 0.08^{\mathrm{a}}$ & $1.52 \pm 0.08^{\mathrm{d}}$ & $1.75 \pm 0.05^{\mathrm{bd}}$ & $0.98 \pm 0.02^{\mathrm{d}}$ \\
\hline
\end{tabular}

1: Day of sampling.

*: MeantS.D.

2,b: Means on the same row with different superscripts are significantly different $(\mathrm{P}<0.05)$.

c,d: Means on the same with column different superscripts are significantly different $(\mathrm{P}<0.05)$. 
Table 2 : Effect of treatment with GnRH on ovarian activity in ewe lambs ${ }^{1}$

\begin{tabular}{|c|c|ccc|c|}
\hline $\begin{array}{c}\text { GnRH } \\
\text { treatment } \\
\text { groups }\end{array}$ & $\begin{array}{c}\text { No. of } \\
\text { Ewe } \\
\text { Lambs }\end{array}$ & \multicolumn{2}{|c|}{ Serum $\mathrm{P}_{4}$ Conc. (ng/ml) } & $\frac{\text { Serum } \mathrm{E}_{2} \text { Conc. }}{\frac{\text { (pg/ml) }}{\text { Day 14 }}}$ \\
\hline I & 12 & $1.42 \pm 0.06^{*}$ & $1.49 \pm 0.10$ & $1.67 \pm 0.06^{\mathrm{a}}$ & $0.99 \pm 0.06^{\mathrm{a}}$ \\
II & 12 & $1.29 \pm 0.14$ & $1.46 \pm 0.12$ & $1.83 \pm 0.04^{\mathrm{b}}$ & $0.76 \pm 0.10^{\mathrm{b}}$ \\
III & 12 & $1.35 \pm 0.07$ & $1.48 \pm 0.07$ & $1.91 \pm 0.13^{\mathrm{b}}$ & $0.58 \pm 0.05^{\mathrm{c}}$ \\
\hline
\end{tabular}

\footnotetext{
${ }^{1}:$ Animals treated with GnRH at day 6 (I); at day 12 (II) and at days 6 \& 12 (III) postmating and pregnant. $\quad{ }^{2}$ : Day of sampling. *: Overall mean \pm S.D.

a,be: Means on same column with different superscripts are significantly different $(P<0.05)$.
}

Table 3 : Effect of stage of breeding season and GnRH treatment* post-mating on reproductive performance of ewe lambs

\begin{tabular}{|c|c|c|c|c|c|c|}
\hline $\begin{array}{c}\text { Stage of } \\
\text { breeding } \\
\text { season }\end{array}$ & $\begin{array}{c}\text { Treament } \\
\text { groups }\end{array}$ & $\begin{array}{c}\begin{array}{c}\text { No. of } \\
\text { ewe } \\
\text { lambs }\end{array} \\
\text { group }\end{array}$ & $\begin{array}{c}\text { No. ewes } \\
\text { lambs } \\
\text { Returning } \\
\text { to } \\
\text { oestrus }\end{array}$ & $\begin{array}{l}\text { Non } \\
\text { return } \\
\text { rate } \\
\text { (No.) }\end{array}$ & $\begin{array}{c}\text { No. of } \\
\text { animals } \\
\text { lambing } \\
(\%)^{1}\end{array}$ & $\begin{array}{l}\text { No. of } \\
\text { animals non } \\
\text { return and } \\
\text { non } \\
\text { lambing } \\
(\%)\end{array}$ \\
\hline Early & $\begin{array}{l}\text { Control } \\
\frac{\text { GnRH }}{\text { I }} \\
\text { II } \\
\text { III }\end{array}$ & $\begin{array}{l}18 \\
19 \\
19\end{array}$ & $\begin{array}{l}6 \\
7 \\
6\end{array}$ & $\begin{array}{l}0.70(14) \\
0.66(12) \\
0.63(12) \\
0.68(13)\end{array}$ & $\begin{array}{l}7(35.0)^{\text {od }} \\
8(44.4) \\
10(52.6) \\
12(63.1)^{b}\end{array}$ & $\begin{array}{l}7 / 14(50.0)^{a} \\
4 / 12(33.3)^{f} \\
2 / 12(16.7)^{68} \\
1 / 13(7.7)^{\mathrm{g}}\end{array}$ \\
\hline Mid. & $\begin{array}{l}\text { control } \\
\text { GnRH } \\
\text { I } \\
\text { II } \\
\text { III } \\
\end{array}$ & $\begin{array}{c}19 \\
19 \\
19 \\
\end{array}$ & $\begin{array}{l}4 \\
5 \\
3 \\
\end{array}$ & $\begin{array}{l}0.84(16) \\
0.78(15) \\
0.73(14) \\
0.85(16) \\
\end{array}$ & $\begin{array}{l}11(57.9)^{\circ 0} \\
11(57.9) \\
13(68.4) \\
15(78.9)^{6}\end{array}$ & $\begin{array}{l}5 / 16(31.2)^{8} \\
4 / 15(26.7)^{f} \\
1 / 14(7.1)^{68} \\
1 / 16(6.2)^{68}\end{array}$ \\
\hline Total & $\begin{array}{l}\text { control } \\
\text { GnRH } \\
\text { I } \\
\text { II } \\
\text { III }\end{array}$ & $\begin{array}{c}37 \\
38 \\
38\end{array}$ & $\begin{array}{r}10 \\
12 \\
9\end{array}$ & $\begin{array}{l}0.73(27) \\
0.68(26) \\
0.76(29)\end{array}$ & $\begin{array}{l}18(46.1)^{\mathrm{a}} \\
19(51.3)^{f} \\
23(60.5)^{\mathrm{bgg}} \\
27(71.0)^{\mathrm{bg}}\end{array}$ & $\begin{array}{l}12 / 30(40.0)^{\circ} \\
8 / 27(29.6)^{\mathrm{f}} \\
3 / 26(11.5)^{\mathrm{bg}} \\
2 / 26(6.9)^{\mathrm{cg}}\end{array}$ \\
\hline
\end{tabular}

: :Animals treated with GnRH [at day 6 (I); At day 12 (II) and at days $6 \& 12$ (III) postmating. '. No. animals lambing per total number of ewe lambs in each treatment.

2,b,c,.,.g: Means on same column with different superscripts are significantly different $(P<0.05)$.

d,e : Means on different row with different superscripts are significantly different $(P<0.05)$. 